\title{
THE UNITED NATIONS UNDER AMERICAN MUNICIPAL LAW: A PRELIMINARY ASSESSMENT
}

WITH public consideration of the United Nations centered on its handling of broad international issues, analysis of how the organization's headquarters will function under American law has been left largely to municipalities and private parties likely to be directly affected. For those believing themselves adversely interested general uncertainty over the status of the U.N. has made it easy to conjure up a host of complexities likely to arise from the location of its headquarters in this country. ${ }^{1}$ Leaving argumentative dissertations to political scientists and others, this discussion is designed to collate the available material on this relatively obscure facet of the U.N. -the jural relationship of the organization to its territorial surroundings.

To the extent that the U.N.'s position in the United States is bound up with questions of fact, such as how many employees the organization will eventually have, where its permanent headquarters will be located, and how large an area it will require, definitive answers will come only with time. ${ }^{2}$

1. E.g., "The UNO in Greenwich?," a handbill distributed by opponents to the inclusion of part of Greenwich in the permanent headquarters zone, pictures the town's water supply endangered; the local brooks turned into nauseating eyesores by U.N.'s sewage; taxes increased $20 \% ; 50,000$ persons immune from all local law; and compensation of less than $50 \%$ for land taken by the U.N. And see N. Y. Times, March 26, 1946, p. 3, col. 8 for reference by a Westchester official to the presence near New York City of U.N. headquarters as constituting a danger to national security. See also Time, Feb. 18, 1946, p. 23; N. X Times, Feb. 20, 1946, p. 2, col. 6 .

2. Neither the size nor exact location of the permanent headquarters zone have been determined. The Preparatory Commission of the United Nations recommended that it be in the eastern part of the United States, and set up an Interim Committee to recommend exact sites. United Nations Document, PC/CD/9, Dec. 22, 1945. This committee narrowed the possible areas to the vicinity of Boston and New York City, and appointed a Site Inspection Group to visit the United States and make definite recommendations. United Nations Document, PC/ICH/W2/Rev. 1, Dec. 28, 1945. The Group inspected possible sites in January, 1946, and recommended a 42-square mile area in Westchester, N. Y., and Fairfield, Conn., counties. Time, Feb. 11, 1946, p. 18. The General Assembly did not adopt this recommendation. Instead, it voted merely to establish the permanent headquarters somewhere in Westchester and/or Fairfield; and a Headquarters Commission was set up to recommend to the General Assembly, when it reconvenes in September, exact locations based on alternate plans for a zone of 2, 5, 10,20, and 40 square miles. Resolution Adopted by General Assembly as to Procedure for Selecting a Site in Westchester County, New York, and/or Fairfield County, Connecticut, Feb. 14, 1946; N. Y. Times, Feb. 15, 1946, p. 1, col. 1. See also Report of U. S. Delegation to the first Part of the First Session of the General Assembly of the U.N., Dept. of State Publication No. 2484 (1946) 15-17. This new commission first met on May 7. N. Y. Times, May 8, 1946, p. 4, col. 2.

There have been reports, however, that local opposition and lack of greater cooperation by the United States government might induce the organization to choose a site in a different part of this country or even in another country. Newsweek, March 18, 1946, p. 23; N. Y. Times, Apr. 14, 1946, § 4, p. 3, col. 7.

In any event, it is estimated that three to five years will be required to prepare the 
The legal aspects of the problem may be analyzed, however, in terms of (1) the bases of the U.N.'s status (2) the nature of that status and (3) the special considerations involved in the establishment of a permanent headquarters zone.

I.

Legal sources. The basic sources of the U.N.'s legal character in the United States are international law, ${ }^{3}$ the U.N. Charter, ${ }^{4}$ and the recent International Organizations Immunities Act. ${ }^{5}$ In addition, the U.N. has submitted to the United States, for hegotiation and eventual adoption as a Treaty or Executive Agreement, a draft convention which would regulate its status in this country with particular regard to the problems of the permanent headquarters zone. ${ }^{6}$

Permanent international organizations formed to exercise even limited functions outside the capacity of individual states are relatively new to

permanent zone for occupancy; present plans call for interim headquarters remaining, in the meantime, at Lake Success, N. Y., and at the former World's Fair site at Flushing Mleadows, N. Y. N. Y. Times, Apr. 11, 1946, p. 1, col. 7; id. Apr. 12, 1916, p. 1, col. 8; id. Apr. 19, 1916, p. 14 , col. 2.

3. When unrestricted by statutory limitations, American courts apply the customs and principles of international law as part of the law of the land. The Paquete Habana, 175 U. S. 677 (1900); The Nereide, 9 Cranch. 388 (U. S. 1815); 1 Hyoe, Intemantonar LAw (2d ed. 1945) 17.

4. The Charter was submitted to the Senate as a treaty and approved July 28,1945 , by a vote of 89 to 2. 91 Cowg. Rec. 8329 (1945). Upon deposit of the necessary number of ratifications, it became effective Oct. 24, 1915. 13 DEPT. OE Srure Bvil. 679 (1945).

5. Pub. L. No. 291, 79th Cong., 1st Sess. (Dec. 29, 1945) Tit. I; ExEc. Orocr No. 9698 (Feb. 19, 1946) 11 FED. REG. 1S09. Discussed infra.

6. There are really two proposed conventions, one dealing with privileges and immunities of the United Nations and its personnel, the other treating the establishment of the permanent headquarters zone. The first has been proposed for accession by all membar nations; the second would be between the United Nations and the United States alone, but includes the provisions of the privileges and immunities convention as an Appendis.

The zone convention has gone through three drafts. The first was prepared trefore it was known in what country the permanent headquarters would be located. United Nations Document, PC/G/24, Dec. 14, 1945. After the appropriate committee of the Preparatory Commission had recommended that headquarters be located in the United States, the Canadian delegation prepared a second and more specific draft which was accepted by the Preparatory Commission and submitted to the General Ascembly. United Nations Document, PC. G/31, Dec. 20, 1945; PC/G/36, Dec. 21, 1945. The General Acsembly incorporated additional revisions in the present draft and submitted it to the Secretary-General for use as a basis of discussions with the United States. Resolution of the Gencral Arzembly as to Negotiation of Arrangements for Control of the Ares to be Selected as a Site for the United Nations Headqquarters, Feb. 13, 1946. American officials participated informally in preparation of the latest draft, but neither the United States nor the United Nations is committed to its provisions. A ten-nation advisory group appointed by the SacretaryGeneral has started negotiation of the convention with State Department officials. N. Y. Times, May 16, 1946, p. 9, col. 1.

It is not known whether the zone convention as finally negotiated will be approved as a treaty (two-thirds vote of the Senate) or an executive agreement (majority vote of both 
international law, ${ }^{7}$ and the status of the U.N. will find little definition from this body of jurisprudence. Courts have seldom had occasion to determine the legal attributes of such organizations; ${ }^{8}$ and writers have generally avoided classifying them in terms of traditional concepts-such as states, federations, colonies, alliances-and have passed over their status under the municipal law of the countries within which they operate. ${ }^{9}$ The League of Nations, the organization most analogous to the U.N., has been characterized as sui generis, ${ }^{10}$ and Switzerland and the League tacitly recognized this view

houses). For an argument that the legal effect would be identical, see McDougal and Lans, Treaties and Congressional-Executive or Presidential Agreements: Interchangeable Instruments of National Policy (1945) 54 YaIE L. J. 181 and 534. For a contrary view, see Borchard, Treaties and Execulive Agreements-A Reply (1945) 54 YALE L. J. 616.

The general convention on privileges and immunities has been approved by the General Assembly and will become effective as regards each member nation on deposit of an instrument of accession. Both conventions have been mimeographed by the State Department under the heading, "Documents Relating to the Selection of the Site for the Permanent Headquarters of the United Nations in the United States and the Arrangements for the Control of the Area Comprising the Site," unnumbered and undated.

7. Commissions were set up under the Treaty of Vienna in $\mathbf{1 8 1 5}$ to execute the treaty provisions relating to navigation on European rivers. WoOLF, INTERNATIONAL GoverN3IENT (1916) 104, n. 4. But it was not until the last half of the nineteenth century that permanent international administrative bodies began to be formed. Since then such bodies have been constituted to deal with a wide variety of economic, scientific and cultural subjects. See Reinsch, International Unions and Their Administration (1907) 1 AM. J. INT. L. 579; 1 Oppenheim, International LaW (5th ed. 1937) App. A.

8. The paucity of judicial precedent at once contributes to theoretical uncertainty and shows that it has not in fact hampered the operation of the organizations. The District of Columbia Municipal Court on Dec. 16,1925, dismissed attachment proceedings against the Pan American Union for lack of jurisdiction; the Union's brief contended that the sovereign status of the Union's members gave it immunity from the process of American courts. Penfield, The Legal Status of the Pan American Union (1926) 20 AM. J. INT. L. 257. A suit against the International Institute of Agriculture for payments allegedly due an employce was dismissed by direction of the Italian Court of Cassation on the grounds that Italian courts had no jurisdiction over the Institute except when it consented. International Institute of Agriculture v. Profili, Italian Court of Cassation, Feb. 26, 1931, ANnunL Dig. of PUB. INT. L. CASEs 1929-30 (1935) 413. A building contractor's claim against the League of Nations was rejected on the merits but doubt was expressed that Swiss courts had jurisdiction over suits against the League. Schmidlin v. Sociéte des Nations, Court of Civ. Just. of Geneva, Feb. 6, 1925, 21 Revú de Droit International Prive 103.

9. What discussion there has been has centered around (a) whether the organizations have "international legal personality," i.e., whether they can hold property, contract, suo, etc. and (b) the privileges and immunities of their personnel. See 1 OPPENHEIM, op. cil. supra note 7, 676-8, especially 678 n. 2; EAGLETON, INTERNaTIONAL GovernMent (1932) 238-9, 268-9; Norsandin, Du Statut Juridique des Associations Internationales (1926) 176-87. It has been remarked that international organizations have been "baptized rather than defined." EAGLETON, supra, at 239. For a thorough consideration of the status of their personnel, see BASDEVANT, LES FonCtIONNAIRES INTERNATIONAUX (1931).

10. 1 Oppenhem, op. cit. supra note 7, at 306 et seq.; see also 1 Bustamante Y SiRVEN, Droit International Public (1934) 492-6; Ames, What Is the League of Nations? (1928) 22 Am. Pol. Scr. Rev. 706; of. Corbett, What is the League of Nations? (1924) Brit. Y. B. INT. L. 119; Voorhees, The League of Nations: A Corporation, Not a Superstate (1926) 20 AM. 
by resorting to a modus vivendi to regulate their relations." Although it would thus appear that the U.N. derives neither "sovereignty" nor an easily predictable legal status from international law, it nonetheless seems likely that even in the absence of legislation or specific international agreement courts would clothe the organization with legal characteristics deemed essential to the performance of the functions for which it was created. Failure to do so would mean acceptance of the premise that the member nations were either unable or did not intend to create a workable institution.

The Charter commits the United States as a signatory to provide the U.N. and its personnel with legal capacity and privileges and immunities "necessary" for the fulfilment of its purposes. ${ }^{12}$ The International Organizations

PoL. ScI. REv. S47; Harriman, League of Nalions a Rudimentary Stuparstale (1927) 21 A2s. Pol. SCI. REv. 137.

11. The League Covenant contained two provisions relative to the League's status under municipal law: (a) representatives of members and officials of the League when engaged in League business would enjoy diplomatic privileges and immunities and (b) the buildings and other property occupied by the League or its officials or by representatives of

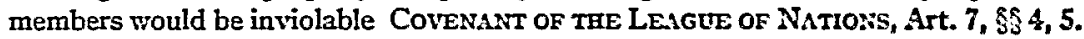

The League and Switzerland did not see eye to eye on the applicability of these provisions, and it was only after long negotiation that the mod:s rircndi was signed in 1926. Significantly, the reporter introducing it to the League Council included the remarls, "Avoiding all discussion on the legal interpretation of Article 7, par. 4 , of the Covenant, the agreement coritains practical rules. . . " League of Nations Document c. 558. 1926. V. Sie also 1 Oppenheds, op. cit. suspra note 7 , at 308, n. 3.

By the modus oireidi the Swiss government recognized that the League had "internstional personality and legal capacity"; that it was immune from suit; that its archives were inviolable; that no public official could enter its buildings vithout permission; that no tases could be imposed on its property or assets; that imports for the League's use were exempt from customs; that salaries of alien officials of the first two clacses (an arbitrary division by rank) would be tax-free; that officials of the first class vould have complete immunity from suit and those of the second class immunity for official acts; and that the League's couriers would have the same status as couriers for foreign governments. Salarics of officials of Swiss nationality were made exempt only from local taxes; and Swiss officials were to be exempted from military service only where their departure would hurt the League. League of Nations Document c. 555. 1926. V.

12. "The Organization shall enjoy in the territory of each of its Mlembers such lezal capacity as may be necessary for the exercise of its functions and the fulfilment of its purposes." Unted Nations Charter, Art. 104.

"The Organization shall enjoy in the territory of each of its Members such privilgzes and immunities as are necessary for the fulfilment of its purposes." Id. Art. 105, $§ 1$.

"Representatives of the Miembers of the United Nations and officials of the Organization shall similarly enjoy such privileges and immunities as are necessary for the indepandent exercise of their functions in connection with the Organization." Id. Art. 105, $\$ 2$.

An added moral obligation to extend assistance to the United Nations in the establishment of its headquarters in this country was created by a Concurrent Recolution of Congres, Dec. 10 and 11, 1945, inviting the organization to locate its seat here. The Recolution was transmitted to the Preparatory Commission just before a decision was to be reached on locating the headquarters in Europe or the United States. 91 Covic. REc. 11930, 11969-70 (1945); Record of Eleventh Meeting, Committee S, Preparatory Commission, Dec. 15, $19: 5$. 
Immunities Act, ${ }^{13}$ which has been applied to the U.N. by Executive Order, ${ }^{14}$ is the only step thus far taken by the United States to implement this pledge. ${ }^{15}$ And even without a convention, further Congressional action reasonably designed to implement the Charter pledge would probably be upheld by the courts. Determination of what measures are appropriate for that purpose might well be deemed a "political question" to be left to the discretion of the executive and legislative branches. ${ }^{16}$ If not, courts might reason that negotiation of the Chàrter fell within the comprehensive federal power in foreign relations; ${ }^{17}$ that as a treaty the Charter is now part of the supreme law of the land; $;^{18}$ and that measures implementing it need only pass the test of being necessary and proper, ${ }^{19}$ which depends again on the functional standard set up in the Charter.

However, the convention method of achieving legal status offers some advantages. From the U.N.'s standpoint, a convention would add an aura of sanctity and permanence to the arrangements ${ }^{20}$ and provide a more

13. See note 5 supra.

14. See note 5 supra.

15. See note 5 supra. The Act recognizes the capacity of "public international organizations" to contract, hold property, and bring suit; and grants the organizations and their personnel various immunities from suit, taxes, and immigration restrictions. As applied to the United Nations, the Act is discussed in more detail infra, passim.

Other organizations thus far brought within the provisions of the Act are the Food and Agricultural Organization; the International Labor Office; the Pan American Union; and the United Nations Relief and Rehabilitation Administration. ExEC. ORDER No. 9698 (Feb. 19, 1946) 11 FED. REG. 1809 (1946).

16. See Republic of Mexico v. Hoffman, 324 U. S. 30 (1945); Jones v. United States, 137 U. S. 202 (1890); Foster v. Neilson, 2 Pet. 253 (U. S. 1829); Willougruy, ConstituTTONal LaW of the UNITEd States (2d ed. 1930) 567-70. Corwin refers to the "settled reluctance of the Court to thrust its oar into the turbulent waters of foreign policy-making." Corwin, The Constitution and World Organization (1944) 24.

- 17. United States v. Curtiss-Wright Export Corp., 299 U. S. 304 (1936); Burnet v. Brooks, 288 U. S. 378 (1933); Fong Yue Ting v. United States, 149 U. S. 698 (1893); see Levitan, The Foreign Relations Power: An Analysis of Mr. Justice Sulherland's Theory (1946) 55 Yale L. J. 467; WiLlougBry, op. cit. supra note 16, at 61-2, 228-9, 240-1; CoRwiN, op. cit. supra note 16, at 17-9.

18. ". . . all treaties made . . . under the authority of the United States shall be tho supreme law of the land; and the judges in every state shall be bound thereby, anything in the constitution or laws of any state to the contrary notwithstanding." U. S. CoNSr. Art. VI, § 2. See WILLoUgary, op. cit. supra, note 16, at 240-5.

". . . state law must yield when it is inconsistent with, or impairs the policy or provisions of, a treaty or of an international compact or agreement." Mr. Justice Douglas in United States v. Pink, 315 U. S. 203, 230-1 (1942). See also Missouri v. Holland, 252 U. S. 416 (1920).

19. U. S. Const., Art. I, $\S 8$, clause 18. WrLLougrey, op. cit. sttpra note 16, at $60-1$, 242-3. Neely v. Henkel, 180 U. S. 109 (1901); see Missouri v. Holland, 252 U. S. 416, 432 (1919).

20. Either a Treaty or Executive Agreement would create a strong moral obligation in the United States to adhere to its provisions, but could be modified or annulled by Act of Congress. WrloughBy, op. cit. supra note 16, at 236; see Van der Weyde v. Ocean Trans- 
forceful example to countries slow in granting its promised status. Moreover, since the terms of a convention would be on the level of supreme law of the land, ${ }^{21}$ the legislative and executive branches of our government could carry out convention promises without risking litigation to determine whether each measure was "necessary" to the United Nations as required by the Charter.

\section{II}

Legal status of the U.N.-the organization and its personnel. The International Organizations Immunities Act gives the U.N. the capacity to contract, to acquire and dispose of property, and to institute legal proceedings; ${ }^{22}$ makes the organization and its property and assets immune from suit or process except as immunity is expressly waived by contract or for the purpose of any proceeding $;{ }^{23}$ exempts it from federal taxes on income, property, communications, and transportation, and from customs duties on official imports $; ;^{24}$ exempts it from the withholding provisions of the personal income $\operatorname{tax}^{25}$ and from contributions under the Federal Insurance Contributions

port Co., 297 U.S. 114 (1936); Piegeon River Co. v. Cos, 291 U. S. 13S, 160 (1934); Coo's v. United States, 288 U.S. 102, 120 (1933).

21. See note 18 supra. This would hold true even if the convention should talie the form of an executive agreement. United States v. Pink, 315 U. S. 203 (1942).

22. Pub. L. No. 291, supra note 5, Tit. I, §2(a).

23. The U.N.'s immunity from suit is defined as the same "as is enjoyed by foreign governments." Id. $\S 2(\mathrm{~b})$. In practice this seems to mean almost complete immunity. Research in International Law of the Harvard Law School, Compleree of Courls in Regard to Foreign States: Draft Consention, wilh Comment (1932), 26 Asr. J. InT. L. Surp. 475, 527, 540, 543, 548, 560, 569, 645; see The Exchange v. MicFaddon, 7 Cranch. 116, 136-7 (U. S. 1812); Wulfsohn v. Russian Socialist Federated Soviet Republic, 231 N. Y. 372, $375-6,138$ N. E. 24, 26 (1923).

If, as seems unlikely, the U.N. should engage in private business, it would probably ba subject to suit in respect to such business or property held in connection therevith. Recearch in International Law of the Harvard Law School, sipra, at 572-4; and esecution might ircue against such property. Id. at 700-14.

It has been argued that states should be subject to suits to determine interests cven in property used for diplomatic purposes, the state receiving ample protection from the prohibition against the enforcement of any court order against such property. Id. at 573,645 , 689-714.

24. Pub. L. No. 291, supra note 5, Tit. I, amending Irr. Rev. Code \$\$ 116(c), 3466(a), $3169(f)(1), 3 \pm 75(b)(1)$ (1939). The exemption from customs is the same as that "accorded ... to foreign governments." Id. §2(d). Under the Secretary of the Treasury's diceretion to "make such rules and regulations as may be necessary" to carry out the administrative provisions of the Tariff Act, exemption from customs duties is extended to official imports of diplomatic establishments of those countries granting the United States reciprocal exemptions. 46 STAT. 759 (1930), 19 U. S. C. § 1624 (1940); CODE FED. REG., Tit. 19, $§ 8.33$ (1939). Presumably exemption will be extended to the United Nations outright since it is not in a position to discriminate against the United States.

Under the Draft Convention, the United Nations would undertalse not to eall articles imported duty-free. Draft Convention, App. II, Art. 2, § 7(b).

25. Pub. L. No. 291 , supra note 5, Tit. I, §4(e) amending Isr. REv. CoDE $\S 1621$ (a)(5) (1939). 
Act and the Federal Unemployment Tax Act; ${ }^{26}$ and accords its communications the same favored treatment as those of foreign governments. ${ }^{27}$

The draft convention includes these provisions..$^{23}$ In addition it proposes U.N. exemption. from state and local taxes ${ }^{29}$ freedom from exchange controls ${ }^{30}$ submission to a referee appointed by the International Court of Justice of disputes between the U.N. and the United States over interpretation of the convention; ${ }^{31}$ and a U.N. pledge to "make provisions for appropriate modes of settlement" of claims by private parties against the organization or its agents whenever immunity from suit is invoked..$^{32}$ If the League's experience is repeated, the U.N. will find it desirable to establish its own administrative tribunal for settlement of employee grievances. ${ }^{33}$

The positive capacities to contract, hold property, and bring suit give the U.N. legal personality similar to that of other "persons" before American law. Since operation as an independent body would otherwise be impossible, it is probable that even in the absence of a statutory grant the courts would

26. Id. $\S 4(\mathrm{c})$, (d) amending Int. Rev. Code $\S \S 1426(\mathrm{~b}), 1607$ (c) (1939). United Nations employees, as a counterpart, will not receive benefits under the Social Security Act. Id. $\S 5$ (a) amending 53 STAT. 1373, § 209(b) (1939), 42 U. S. C. $\$ 409$ (b) (1940).

27. $I d . \$ 2(\mathrm{~d})$.

28. Draft Convention, App. II, Art. I, II $\S \S 2,3,4,7$, III.

29. The provision is phrased to achieve exemption "from all direct taxes." Id. App. II, Art. II, § 7. In addition, the United States would whenever possible arrange for remission of excise and sales taxes on United Nations purchases for official use. Id. App. II, Art. II, $\S 8$. For its permanent headquarters, and presumably for the interim one, the United $\mathrm{Na}$ tions intends to contract for public services such as gas, water, electricity, drainage, and refuse collection. Id. Art. VII, $\S 28$. Where services are supplied by local governments and not private corporations, the contracts will probably be negotiated to compensate at least in part for loss of revenue from local property taxes. A resolution of Feb. 13, 1946, by the Headquarters Committee of the General Assembly promised "friendly consideration to any problems ... in connection with ... tax, revenue, and other problems affecting the localities involved" when the permanent headquarters site is selected. The Nassau County Executive has acknowledged the United Nations' willingness to pay a "fair share" of local taxes in connection with the use of the Sperry Plant at Lake Success, N. Y., as an interim office building. N. Y. Times, April 12, 1946, p. 2, col. 7. It is also possible that increased assessment values of land adjacent to the permanent headquarters will make up for loss of property taxes from the zone itself.

30. The organization could hold funds of any kind, operate accounts in any currency, and transfer its funds as desired. Id. App. II, Art. II, $\S 5$.

31. Id. Art. X, § 39. In the course of proceedings by the referee either party could ask, through the General Assembly, for an advisory opinion of the International Court on any legal question arising. The referee would render a final decision "having regard to the opinion of the Court." Id. $\S 40$. In case of a dispute between the U.N. and a state, the state's interests would presumably be represented through the United States. The U.N. could not sue the state. Principality of Monaco v. Mississippi, 292 U. S. 313 (1934).

32. Id. App. II, Art. VIII, $\S 29$ (a), (b). Under the International Organizations Immunities Act, employees of the U.N. are immune from suit for acts performed in their official capacity. Pub. L. No. 291, supra note 5, Tit. I, § 7(b).

33. The League's tribunal dealt exclusively with claims under employment contracts. It was established in 1928. Ames, supra note 10, at 709-10. 
have recognized such powers as inherent in the organization or implied from the United States pledge to provide "necessary" legal capacity.

The proposed jurisdictional and fiscal immunities correspond with those accorded foreign governments. ${ }^{34}$ Justification for immunity from suit rests, however, not on concepts of sovereignty or extraterritoriality, but on the argument that the U.N.'s independence would be prejudiced by subjection to judgment and execution by courts of a member nation and its efficiency impaired by possible harrassing actions. In extending immunity from taxation, the International Organizations Immunities Act probably does no more than anticipate conclusions which courts would reach under international law. The U.N.'s sole source of revenue is assessments on member nations; a tax on the U.N. would in effect be a tax on those nations; and sovereign states and their official property are generally considered beyond the taxing jurisdiction of other states. ${ }^{35}$ Besides, it would seem incongruous for the United States to deny the top organization for world cooperation the same immunity regularly accorded to domestic educational, fraternal, and charitable institutions. ${ }^{36}$

While submission to a referee of disputes between the United Nations and the United States seems satisfactory, and the settlement of employee claims is properly a U.N. responsibility, the United States should insist on provision of specific machinery to protect the interests of individuals and corporations dealing with the U.N. Even though it is in the organization's own interest to treat fairly with private parties, disputes sounding in both contract and tort will inevitably arise. Except where waiver of immunity or arbitration is specified in contracts, the U.N. can now deny any recourse except through diplomatic channels. The proliferation of international organizations with at least partial immunity from suit has brought forth suggestions for a coordinated system of international courts. ${ }^{37}$ Pending possible implementation of such proposals, the convention should require the U.N.

34. For jurisdictional immunities see note 23 supra. In general the same considerations apply to the fiscal immunities of sovereign states. See 1 HxDE, op. cit. stspro note 3, at 666, ก. 16.

35. See note 34 supra.

36. See, e.g., INT. Rev. Code $\$ 101$ (1939); N. Y. Const. Art. XVI, \$1; N. Y. Tax Law $\S 4(6)$; Conn. Gen. Stat. (1930) § 1163; Conn. Gen. Stat. Supp. (1939) $§ 354$ e.

37. See Kuhn, Unitcd Nations 1 onelary Conference and the Inmun:ly of International Agencies (1941) 38 Axr. J. INr. L. 662, 666-7; Murdocls, Post-War Interrational Judtcial Organization (1941) 38 Axr. J. INT. L. 706; Preliminary Report of the Commiccion to Study the Organization of Peace (1941) International Coscilitio: No. 369 at 505.

Only states can be parties in cases before the International Court of Justice. Srarcre of the International Court of Jostice, Art. 34, $\$ 1$. The statute of the Court vould therefore have to be amended if private parties were to have an appeal to the Court from any set of subordinate international tribunals. It has been argued that such extension of the Court's jurisdiction would give it "functions it could not perform without danger to its original and proper functions," and a separate set of international courts for private international law has been proposed instead. Hostie, The Slalule of llse Pormarrat Courl of Yrternational Justice (1944) 38 Asr. J. INT. L. 407, 420-2. 
to set up a claims court or arbitral machinery for civil actions by aggrieved private parties.

Under the International Organizations Immunities Act alien employees of the U.N., employees of American citizenship, and representatives of foreign governments to the U.N. already enjoy immunity from suit and legal process for "acts performed ... in their official capacity and falling within their functions" except as immunity is waived by the U.N. or the foreign government. ${ }^{38}$ Exemption from federal income taxes on their salaries is enjoyed by alien employees unconditionally; ${ }^{39}$ by representatives of foreign governments on condition their governments grant reciprocal exemptions to American officials serving abroad with international organizations; ${ }^{40}$ but not at all by American employees. ${ }^{41}$ Alien employees and representatives of foreign governments have exemption from customs duties on baggage and personal effects brought with them on arrival in the United States but not for anything imported subsequently $;^{42}$ are not considered immigrants for the purpose of entering the United States $;^{43}$ and are exempt from regulations for alien registration and fingerprinting and registration of foreign agents. ${ }^{44}$

Proposals in the draft convention would result in extending immunity from suit to the private acts of the U.N.'s top officials and resident representatives of members; ${ }^{45}$ including American employees in the exemption from

38. Pub. L. No. 291, supra note 5, Tit. I, $\S 7$ (b). The Secretary-General would have the right and duty of waiving immunity for any employee even against the will of the $\mathrm{cm}$ ployee whenever, in his opinion, it could be waived without prejudice to the United Nations. Draft Convention, supra note $6, \mathrm{App}$. II, Art. V, $\$ 20$. It would likewise be considered the right and duty of foreign governments to waive immunity for their representatives under similar circumstances. Id. App. II, Art. IV, § 14.

39. Id. $\S 4(\mathrm{~b})$ amending INT. REv. CODE § 116(h)(1) (1939).

40. Ibid.

41. INT. Rev. CODE $\S 116$ (h)(1) (1939) as amended by Pub. L. No. 291, see supra note 5, Tit. I, $\S 4$ (b).

42. Pub. L. No. 291, supra note 5, Tit. I, §3.

43. Id. $\S 7$ (c) and (d) amending the Immigration Act, 43 STAT. 154 and 162 (1924) as amended, 8 U. S. C. $\S \S 203$ and 215 (1940). They must, however, obtain permits to enter the country. Code Fed. Reg. CuM. SUPP. (1943) Tit. 8, \$§ 175.42, 175.52.

44. Alien employees of the U.N. and representatives of foreign members are given the same status as officers and employees of foreign governments. Pub. L. No. 291, supra note 5, Tit. I, $\S 7$ (a). This means exemption from alien registration and fingerprinting. 54 SruT. 674 (1940), 8 U. S. C. $\$ 453$ (b); Code FEd. REg. CuM. Supp. (1943) Tit. 8, § 170.1(h). Exemption from registration as foreign agents is dependent on the employee's status and duties being on record at the State Department. 52 STAT. 631 (1938) as amended by 56 STAT. 254 (1942), 22 U. S. C. $\$ 613$ (1943 Supp.); Agents of Foreign Principals and of Forcign Governments, Dept. of State Publication No. 1370 (1939) Part I, Ch. IV, $\$ 18$.

45. The Secretary-General, Assistant Secretaries-General, and resident representatives of members would be accorded the privileges and immunities of diplomatic envoys. Draft Convention, Art. V, $\S 25$, App. II, Art. V, §19. By statute and international law such envoys have absolute immunity from criminal or civil suits. REv. STAT. $\$ \$ 4063-5$ (1875), 22 U. S. C. $\S \S 252-4$ (1940); see The Exchange v. McFaddon, '7 Cranch. 116, 138-9 (U. S. 1812); 1 OpPENHEIM, op. cit. supra note 7, at 616-18. There are eight Assistant SecretariesGeneral. N. Y. Times, Apr. 4, 1946, p.4, col. 4. 
federal income taxes on salaries; ${ }^{46}$ exempting U.N. salaries from state taxation; $;^{47}$ exempting all employees and representatives of foreign governments from selective service; ${ }^{48}$ and in recognition by the United States of U.N. passports. ${ }^{49}$

Immunity from suit for U.N. employrees in their capacity as agents appears necessary to free the organization's activities from possible interference by United States courts, for without it the organization's own immunity would be ineffective. It seems that complete immunity from suit should be granted as proposed to a handful of top U.N. officials since legal harrassment in these cases, even for private acts, would hamper the organization. As in the case of the organization, however, the counterpart of any immunity from suit in American courts should be the establishment of alternative machinery for efficacious settlement of disputes when immunity is not waived."

Delegations from member nations are functionally a part of the U.N., and immunity for their personnel when acting in an official capacity is well designed to insure independence in performing their duties. Extension of this immunity to private acts as in the case of ambassadors would seem vise to avoid embarrassment attendant on legal heckling based on political sentiment; whether such extension should be conditioned on reciprocity to American delegations with international organizations is a matter of political strategy. Since the U.N. has no power to bind personnel of foreign governments, any arbitration arrangements in the convention would not be binding upon them; private parties must look to the State Department for protection in disputes with U.N. delegates from foreign sovereigns just as in the case of diplomatic representatives to the United States.

There are two arguments for exempting alien employees' salaries from federal income taxes, as already done, and from state taxes as proposed. One is that exemption would enable the U.N. to pay less for personal services. The other is that salaries of some employees might otherwise be subject to double taxation-by the United States and the country of origin. Many attempts have been made in the last twenty-five years to arrange inter-

46. Draft Convention, App. II, Art. V, $\$ 18(b)$. The United States, not finally committed to any provisions of the draft convention, specifically reserved its position on this one.

47. Ibid.

48. Id. App. II, Art. V, § 18(c). The United States has reserved its position on this proposal in so far as it applies to American citizens.

49. Id. App. II, Art. VII.

50. See p. 785 supra. In the absence of vaiver, American courts would presumably decide whether an act was done in an employee's official capacity and, when the decision went against the employee, proceed to judgment. A different situation might arice under the proposed convention. A dispute between the United States and the U.N. would come into being when the American court decided the jurisdictional issue against the employee. The U.N. might then vaive his immunity, but could refer the question to a referee appointed by the International Court. In such case, the American court would proceed to judgment on the merits at the risk of colliding with a referee's decision which the United States wo committed by convention to respect. 
national agreements to prevent such double taxation, but the problem is far from solution, and without the exemption granted by the United States, would constitute a serious bar to the recruitment of a truly international U.N. staff. ${ }^{51}$ Even with the United States exemption, employees will be subject to taxation at different rates by different countries; U.N. personnel policy therefore calls for paying equal net salaries after taxes. ${ }^{52}$

The United States has told the U.N. that it may not approve the proposal to exempt salaries of American employees, presumably on the grounds that its only justification lies in reducing U.N. costs and that a similar rationale has not been considered cogent enough in this country to exempt federal and state salaries from income taxes. ${ }^{53}$ But the question should be viewed in the light of U.N. proposals that all member nations exempt from taxation the

51. Without the United States exemption, alien employees spending more than nincty days in this country would probably pay American taxes on at least that part of their salaries considered, on a time basis, to have been earned here. INT. REv. CoDE $\$ \$ 119$ (a)(3), 211(b)(1939). In most cases those working in the United States the year-round would probably not be taxed also by the country of origin, since most countries base income taxes on either the source of the income or the residence of the recipient-not on citizenship. However, many employees, particularly technical experts or members of subordinate organizations, may work in this country only part of any year; and some of them would be subject to taxation of their entire salaries by the country of "permanent" residence. For a general discussion see $\mathrm{Ke}$ Chin Wang, International Double Taxation of Income:Relief Through International Agreement 1921-45 (1945) 59 HARv. L. REv. 73. While generalization is difficult in this field, actual experience of the United Nations Relief and Rehabilitation Administration has shown double taxation to be a "major problem" in recruiting an international staff. UNRRA, Report of the Director-General to the Second Session of the Council, Council II, Doc. 1, Sept. 1944, p. 80.

52. The potential inequality of net salaries for employees of the same class has been heightened by the United States exemption; by virtue of it, some alien employees, resident in this country the year-round, may pay no taxes at all on their salaries. The U.N.'s present policy is to pay uniform salaries for each type of work and covenant in employment contracts to reimburse employees for taxes. It is logical to suppose that reimbursement will be based on the amount of taxes employees would pay if the salaries were their only income.

To simplify its book-keeping, the U.N. presumably will attempt to tabulate standard sums for which it will be liable to each class of employees of each nationality. If account is taken of varying exemptions claimable for different numbers of dependents, additional subdivisions will be necessary. Beyond that, other complications will arise under the tax laws of each country. With American employees, for example, it may be convenient to assume that the standard $10 \%$ or $\$ 500$ deduction will be taken and that no employee will file a joint return; and since the amount of reimbursement for taxes on the original salary received might itself be taxable and so on for each subsequent reimbursement, algebraic formulas would be necessary if ultimate liability to each class of American employees were to be calculated with mathematical fineness. Whatever procedure is adopted on these questions, the U.N. will have to figure the amount of reimbursement each employee is entitled to; it might be advisable for it to pay that amount directly to the taxing government so as to permit employees to claim a lump sum credit rather than have to file complicated individual returns.

53. Helvering v. Gerhardt, 304 U. S. 405 (1938) (federal taxation of state salaries); Graves v. New York ex rel. O'Keefe, 306 U. S. 466 (1939) (state taxation of federal salaries). INT. REv. CODE § 22(a) (1939). 
compensation their nationals receive from the organization. General agreement to do so would greatly simplify the boolkeeping problem of adjusting net salaries to a multitude of tax laws, and if the United States is hesitant to take the lead in establishing this principle, it might at least accept on condition that a certain number of other members follow suit.

There seems to be little objection to the other exemptions already granted or proposed in the convention. In exempting on a reciprocal basis the salaries of representatives of foreign governments to the U.N., the International Organizations Immunities Act merely puts these representatives on a par with other employees of their governments in the United States. ${ }^{55}$ Recognition of U.N. passports would be a recognition of the independence from national ties of the organization and its officials; without it, requests for passports would have to be channelled through an official's country of origin. Exemption from selective service, like tax exemption, should be extended to alien employees to encourage recruitment of an international staff but conditioned on reciprocity for representatives of foreign governments; the argument for exempting American employees is that it would free them to some extent from national bonds, and since the number involved should be relatively small the United States has little to lose by granting it."s

\section{III}

Juridical concept of the permanent headquarters sone and the acquisition of property. While neither the size nor exact location of the permanent headquarters zone have been determined, ${ }^{57}$ the U.N. seems to have veered away from any desire to have a completely autonomous zone and to have in mind a concept more similar to an oversize embassy than to a state-within-a-state. ${ }^{.3}$ - Under the proposals in the draft convention, the zone would remain part of

54. The proposal which would exempt salaries of American employess is contained in Appendix II of the draft U.N.-U.S. convention, which is the same as the General Convention already proposed by the U.N. to all member nations. See notes 6 and 46 stspra.

55. INT. REv. CODE $\S 116(\mathrm{~h})(1939)$ prior to amendment by Pub. L. No. 291, stspre note 5, Tit. I.

56. The number of persons involved would be much less than involved in the proposad exemption of salaries of American employees from income taxes, since all employes would draw salaries but only a fev would be males meeting the age and physical requirements for selective service. Whether it would be politically wise for the U.N. to malse itself a haven from selective service, especially when the number of employees concerned would be small, is another matter.

57. See note 2 supra.

58. This conclusion is implicit in the draft convention, which malses no mention of autonomy but sets forth proposals for modifying in specific ways the present legal status of the area which will be taken for the zone. Dr. Gabrilovitch, head of the original Site In spaction Group and a member of the new Headquarters Commission, has stated that an early proposal for an "internationalized community" has been rejected. N. Y. Times, March 4, 1946 , p. 1, cols. 6, 7. The subcommittee which worked out the first form of the draft convention decided not to take as a model any existing arrangement such as the Vatican City, the 
the United States and of the states in which it was located. ${ }^{69}$ The U.N. would have full title to the land and buildings in the zone; the right to take water but not minerals from the subsoil; control of the air space; power to regulate construction; and control over entry into the zone and conditions under which persons might remain there. ${ }^{60}$ The U.N. would undertake not to permit the zone to be used as a refuge for persons avoiding arrest or serv* ice of process, and would receive a United States guarantee of unimpeded transit to and from the zone for persons having official business there. ${ }^{01}$

The United Nations would have authority to enact "regulations making. provisions of an administrative character" for the zone. ${ }^{62}$ These regulations would prevail over any inconsistent American laws, but in no event would the basic freedoms guaranteed by the United States Constitution be abridged within the zone. ${ }^{63}$ Subject to such regulations, the ordinary American civil and criminal law would apply in the zone. ${ }^{64}$ American courts would be bound to give effect to any U.N. regulations to which the United States had agreed, ${ }^{65}$ and American officials would have to get the Secretary-General's permission before entering the zone for service of process or other official purposes. ${ }^{66}$ Otherwise American courts would have the same jurisdiction over acts done in the zone as they now have. ${ }^{67}$ If American citizens continued to reside in the zone, they would retain suffrage and other rights of state and national citizenship. ${ }^{68}$

The U.N. would rely on American governments or corporations for most of the public services needed by its headquarters. Although the organiza-

League of Nations, or the District of Columbia, but to fashion a sui generis regime based on the functional needs of the U.N. Summary Record of Fifteenth Meeting, Committec 8, Preparatory Commission, Dec. 20, 1945, U.N. Document PC/G/28 Supp. No. 8.

59. This is the clear implication of the lack of any provision to the contrary in the Draft Convention. Federal and state officials have privately agreed with this interpretation.

60. Draft Convention, Art. II, $\$ \S 3,6-8$, Art. III, $\$ \S 10,12$. Either directly or by implication the convention would give the United Nations authority to establish any installation deemed necessary for its work and in particular its own radio station, a railroad station, and an airport.

61. Id. Art. III, $\S 14$, Art. IV, $\S \S 19-21$. The U.N. would recognize the United States' right to take such precautions as national security demanded in connection with transit guarantees. Id. Art. IV, $\$ 24$.

62. Id. Art. III, $\$ 16$.

63. The Constitutional rights protected would be "personal liberty and . . . the basic human freedoms of expression and worship." Ibid.

64. Id. Art. III, $\S 15$.

65. American courts would "take cognizance of" all U.N. regulations but be obliged to "inflict penalties for infraction" of only those previously agreed to. Id. Art. III, § 18.

66. Id. Art. III, § 13.

67. Id. Art. III, $\S 17$. Jurisdiction of American courts would also be restricted by the privileges and immunities enjoyed by the U.N. and its personnel, but this restriction would be applicable regardless of the legal status of the headquarters zone.

68. Memorandum from Governor Baldwin to the Connecticut Commission on Intergovernmental Cooperation, Feb. 27, 1946, p. 3. The draft convention was prepared on the assumption that no private persons would live in the zone; the State Department says the 
tion will provide guards for its buildings, ${ }^{, 3}$ the United States would be responsible for furnishing internal police on request and for policing the boundaries of the zone. ${ }^{70}$ Other services, such as electricity, water, gas, post, telephone, telegraph, drainage, and refuse collection, the U.N. would purchase on a contract basis from surrounding communities and utility companies. ${ }^{71}$ The United States' responsibility would be limited to attempting to insure that such services were made available at fair prices and that they were not interrupted. ${ }^{72}$ If U.N. employees live within the zone ${ }^{73}$ and want to send their children to American public schools, either they or the organization will presumably have to negotiate the matter vith neighboring communities.

In discarding any idea of complete autonomy the U.N. sidesteps political and constitutional questions which outright cession of territory would raise; $;^{\text {it }}$ makes unnecessary the maintenance of separate local government; obviates the continuing legal complications which autonomous jurisdiction would provoke $;^{75}$ and yet secures the requisite physical independence for the performance of its functions. Recognition of the U.N.'s power to issue administrative regulations for the zone would give the organization, but to a lesser degree, the same type of "home rule" customarily enjoyed by" municipalities.

The convention would make the United States responsible for (a) expropriating and conveying to the U.N. all land and buildings within the zone selected $;^{76}(\mathrm{~b})$ vesting in the U.N. title to such additional land as it

final version will make "appropriate provisions as to the rights" of any private residents. While the number of private residents remaining in the zone vill probably depend on the size of the area finally selected, U.N. officials have stated that residents would be displaced only where their properties would have to be demolished for construction of U.N. buildings. N. Y. Times, Miarch 4, 1916, p. 1, cols. 6, 7.

69. N. Y. Times, March 14, 1946, p. 8, col. 5.

70. Draft Convention, Art. VI, $\$ \S 26,27$. The United States would "cause to be provided" sufficient police; there seems to be nothing to prevent state or local police from taing used.

71. Id. Art. VII, $\S 28$.

72. The United States would "exercise all the powers . . . it possesses to ensure that the zone . . . [is] supplied on equitable terms" with necessary public services. In case of interruption by a strike or otherwise, the United States would take "those steps which it would take in case of interruption . . . of these services to the essential departments of the United States. . . ." Ibid.

73. There has been no definite indication whether the zone will include living facilities and, if so, for how many persons. The terms of reference for the original Site Inspection Group included a mention of dwellings within the zone. U.N. Document PC/ICH/WS Rev. 1, Dec. 28,1915, p. 3. More recent indications that the zone will be smaller than the recommended 42 -square miles cast doubt on this point.

74. The view has been expressed, however, that the United States could, by treaty, constitutionally alienate territory. 1 WHLOUGEBY, Cosstitutional L.hW of IIL Ummo States (2d ed. 1929) $421-5$.

75. For a discussion of comparable problems arising from exclusive federal juricdiction over federal enclaves within states, see Comment (1938) 38 CoL. L. REv. 128.

76. Draft Convention, Art. II, $\S 3,4$. 
requires in the future $;^{77}$ and (c) insuring that neither the amenities of the zone nor the purposes for which it is used are prejudiced by any use of adjacent land. ${ }^{78}$ The "fair price" of property conveyed to the U.N. would be set off against future United States contributions. ${ }^{79}$

While the U.N. will probably acquire by private purchase as much of the zone as possible,,$^{80}$ a proclaimed intent to resort to condemnation if necessary should reduce speculation, and its exercise would speed acquisition ${ }^{81}$ and insure clear titles. ${ }^{82}$ Condemnation by the federal government, authorized by Congress, should encounter no insurmountable constitutional hurdles. The only major issue would be whether use for U.N. headquarters is a "public use" of the United States. ${ }^{83}$ The Supreme Court has never found that a legislative determination that a use was public exceeded constitutional

77. The proposal extends to "such further land as may be required for . . . constructing an airport, railway station, or radio telegraphic station or for such other purposes as may be required by the United Nations. Id. Art. II, \& 8 . If such land were not contigutous to the rest of the zone, the United States would guarantee unimpeded transit between the parts. Id. Art. II, $\S 9$.

78. Id. Art. VII, § 29.

79. Id. Art. II, $\$ 5$.

80. Such, at least, is the hope attributed to the State Department. Time, Feb. 18, 1946, p. 23, col. 1; Greenwich Time, Feb. 21, 1946, p. 1, col. 8.

81. The federal government may acquire title immediately on filing a Declaration of Taking and depositing with the court the estimated compensation. 46 SrAT. 1421 (1931), 40 U. S. C. \$258a-e (1940). Cf. N. Y. Condennation L. $\$ 24$ and Conn. Gen. Stat. Supp. (1939) $\S 1310$ e, authorizing courts to order immediate entry upon condemnor's maling a deposit if the public interest would be prejudiced by delay.

82. Condemnation proceedings aim at final determination of the condemnor's obligations. United States v. Dunnington, 146 U. S. 338 (1892); Lenhoff, Development of the Concept of Eminent Domain (1942) 42 CoL. L. REv. 596, 630-7; see Duckett \& Co. v. United States, 266 U. S. 149, 151 (1924). Holders of interests wiped out by the condemnation are considered to have equitable liens on the award. Matter of City of New York (Houghton Ave.), 266 N. Y. 26, 193 N. E. 539 (1934). For different methods followed in apportioning awards between holders of various estates, see (1943) 43 CoL. L. REv. 137; (1943) 41 Mrcr. L. REv. 1177 .

83. The power of eminent domain is not expressly delegated to the federal government, but "results from the powers that are given, and it is implied because of its necessity, or because it is appropriate in exercising those powers." United States v. Gettysburg Electric Ry., 160 U. S. 668, 681 (1896); Kohl v. United States, 91 U. S. 367 (1876). It may also be implied from the Constitutional limitation that private property cannot be "taken for public use without just compensation." U. S. CoNST. AMEND. V.

Doubts of the constitutionality of expropriation for the U.N. have been created by a dictum that "eminent domain . . . is a right belonging to a sovereignty to take privato property for its own public uses and not for those of another." Kohl v. United States, supra, at 373-4. But the Court was alluding to the practice of state governments in condemning land for the federal government and commenting on the absence of any necessity for the state to do so.

If the taking is for a public use, its necessity and expediency are legislative, not judicial questions. North Laramie Land Co. v. Hoffman, 268 U. S. 276 (1925); Georgia v. Chattanooga, 264 U.S. 472 (1924). 
bounds, 84 and in a recent decision held that "it is Congress' function to decide what type of taking is for a public use." ss As regards the United Nations, moreover, a decision upholding the government's power would be the only logical alternative to announcing that vorld peace is not a legitimate public purpose of the United States.

Condemnation by the states should also be feasible. The limitations on eminent domain in the New York and Connecticut constitutions are similar to that in the Fifth Amendment of the United States Constitution; ${ }^{25}$ and since tangible and intangible benefits should redound to the states from the presence of U.N. headquarters, it should not be difficult to persuade their courts that provision of land necessary for the headquarters would serve a public purpose. 87

84. See Mr. Justice Frankfurter, dissenting, in United States ex rcl. T. V. A. v. Welch, 66 Sup. Ct. 715, 720 (U. S. 19:6).

S5. United States ex rel. T. V.A. v. Welch, 66 Sup. Ct. 715, 717 (U.S. 1946). The recult would be the same if the courts held that condemnation, being an implementation of the Charter or a convention, was a political question. See note 16 supra.

86. N. Y. Const. Art. I \& 7; Cons. Consr. Art. I, $\S 11$. At an early stage in the discussion of the headquarters zone, it was believed that N. Y. SraTE L. $\$ 50$, which grants state consent to the acquisition of land by the federal government for certain specificd purposes, would have to be amended if the United States were to condemn land in New Yorls for the headquarters. The question of state consent, however, arises in connection with the transfer of jurisdiction over state land to the federal government. Since there seems to be no desire for the United States to assume added jurisdiction over the zone, no statutory change appears necessary.

It has been thought that state exercise of eminent domain was subject to attacls under the due process clause of the United States Constitution as vell as under the "public use" limitations of state constitutions. The main support for this proposition is a dictum in Cincinnati v. Vester, 281 U.S. 139, 416 (1930) in which the court said "It is well established that in considering the application of the Fourteenth Amendment to cases of espropriation of private property, the question what is a public use is a judicial one." While not directly in point, United States ex rel. T. V. A. v. Welch, 66 Sup. Ct. 715, 718 (U. S. 1046) casts doubt on that view. Mr. Justice Black, writing for the majority, goes out of his way to cite the dictum quoted supra, and points out that the decision rested on the ground that state las; had not authorized the questioned condemnation. It is believed there is no cass in which the Supreme Court has held invalid under the Fourteenth Amendment any condemnation proceeding upheld by state courts as being for a public use. See Hairston v. Danville \& W. Ry., 208 U. S. 598, 607 (1908).

87. Recognition of the benefits expected to result to localities from the presence of U. N. headquarters appears in the eagerness with which American states and municipalities attempted to persuade the organization to select a zone in their vicinity. By December, 1945, the U.N. had received over 40 invitations, and in that month sisteen communities even sent deputations to London to argue their cases. Journal of the Preparatory Commission, Dec. 13, 1945; Report from Subcommittee on Hearings, Seventeenth Mreeting, Committee 8, Preparatory Commission, Dec. 22, 1945.

There is of course no case directly in point, but dicta in leading cases in both New Yorl: and Connecticut show that the concept of "public use" in both states is flexible enough to permit expropriation for the United Nations. E.g., "Over many years . . . courts have vainly attempted to define comprehensively the concept of a public use. . . . They have found ... that to formulate anything ultimate ... would, in an inevitably changing 
The easiest way for the U.N. to make sure that additional land will be available for expansion and that use of adjacent land will not prejudice the amenities of the zone would be to purchase or receive from the United States at the outset, a surrounding belt of property. The cost of such an initial purchase and the objections of surrounding communities make this procedure impractical. Instead, the proposed commitments by the United States to condemn additional land when required and to restrict immediately the user of peripheral property should provide a workable alternative. However, prompt planning is required to insure that construction of housing and other facilities near the zone will not follow the haphazard pattern typical of American boom towns. The land may fall in several communities of two states. ${ }^{88}$ To prevent spot incursions by private interests in communities hungry for tax revenue, something more than voluntary cooperation of local zoning boards is needed. Knowledge that the federal government would act if necessary should spur the states to action. At the least they should enact coordinated zoning statutes for the entire area. ${ }^{89}$ More satisfactory results could be obtained by condemning the surrounding area and then leasing or selling the excess land subject to restrictive covenants. The states would thereby minimize the possibility of administrative variances defeating the purpose of zoning laws and reap for themselves any increase in value of adjacent land.90 It is doubtful, however, whether such excess condemnation could be followed under present judicial concepts of "public use." 01

world, be unwise if not futile." New York City Housing Authority v. Muller, 270 N. Y. $333,340,1$ N.E. (2d) 153,155 (1936)." "Use . . . by everybody and anybody is one of the abandoned universal tests of a public use." Id. at 342, 1 N. E. (2d) 155. "In this state it is settled that public use means public usefulness, utility, or advantage, or what is productive of general benefit so that any appropriating of private property ... . for purposes of great advantage to the community is a taking for public use." Board of Water Comm'rs of Hartford v. Manchester, 87 Conn. 193, 204, 87 At1. 870, 873 (1913), aff'd per curiam in Manchester v. Board of Water Comm'rs of Hartford, 241 U.S. 649 (1916).

88. See note 2 supra.

89. If two states are involved, the creation of a joint zoning board would facilitate uniform administration. Congressional consent to negotiation between the states and the creation of such a board would undoubtedly be forthcoming. It is not certain that consent would be necessary. See U. S. Const. Art. I, §10; Virginia v. Tennessee, 148 U. S. 503 (1893); Frankfurter and Landis, The Compact Clanse of the Constitution-A Study in Interstate Adjustments (1925) 34 Y ALE L. J. 685, 749-54.

90. The states and local communities would get added tax revenue from any increase in value of the land whetler or not resort was had to excess condemnation. For European experience in recouping increases in land values resulting from near-by public developments see WALKER, URBAN BLIGHT AND Sluds (1938) 336-7.

91. Excess condemnation has long been urged as an essential technique to assure the full benefits of municipal developments such as slum clearance, construction of low-cost housing, and widening of streets, where the condition of adjacent land threatens the success of the projects. Even when practiced on a very limited scale to condemn odd remnants of plots actually used for the development, it has often run into judicial disfavor in the absence of specific Constitutional permission. Doctrinal opposition stems from "public use" clauses of state constitutions, the argument being that taking for sale back to private parties is not 
for a public use regardless of the value to the municipality of the restrictive covenants imposed. The New York Constitution, Art. I, \& 7(e) provides for a very limited exeers condemnation; the Connecticut Constitution is silent on the subject. See, generally, Cusmens;, Excess Condexination (1917) 275-310; Comment (1946) 46 CoL. L. Rev. 103; Comment (1942) 27 WASE. U. L. Q. 466; Comment (1932) 18 VA. L. REv. 580.

See note 86 supra for an indication that excess condemnation, if upheld by state courts, would not run afoul of the Fourteenth Amendment of the United States Constitution. Cincinnati v. Vester, 281 U. S. 439 (1930), cited therein, involved excers condemnation under an Ohio statute. 